\title{
Hybridisation of picoeukaryotes by eubacterial probes is widespread in the marine environment
}

\author{
Isabelle C. Biegala ${ }^{1, *}$, Matthew Cuttle ${ }^{2}$, Isabelle Mary ${ }^{3}$, Mike Zubkov ${ }^{3}$ \\ ${ }^{1}$ Institut de Recherche pour le Développement, UR167 CYROCO, Centre d'Océanologie de Marseille, \\ rue de la Batterie des Lions, 13007 Marseille, France \\ ${ }^{2}$ Neurosciences Research Group, School of Biological Sciences, University of Southampton, Bassett Crescent East, \\ Southampton SO16 7PX, UK
}

${ }^{3}$ National Oceanography Centre, Southampton, George Deacon Department, European Way, Southampton SO14 3ZH, UK

\begin{abstract}
Most general and group-specific eubacterial probes hybridised picoeukaryotes in coastal waters (Brittany, France) and cultures of the dominant picoeukaryotes from this environment (Micromonas pusilla and Pelagomonas calceolata). This is either because they matched the 16S rRNA from organelles or because of the presence of symbiotic or antagonist intracellular bacteria. The general eubacterial probe (EUB338) hybridised $84 \%$ of the picoeukaryotes, while the group-specific probes hybridised 3,16, 10 and $34 \%$ of the picoeukaryotes for cyanobacteria (CYA664), alphaproteobacteria (ALF968), gamma-proteobacteria (GAM42a) and Cytophaga-Flavo-Bacteria (CF319), respectively. The results show that the hybridisation of eukaryote 16S rRNA by prokaryote probes can lead to significant errors in prokaryote counts, in particular for less well-represented groups such as cyanobacteria, with errors of $17 \%$ in the studied sample. In addition, we revealed for the first time at this scale that up to $44 \%$ of the picoeukaryotes contained intracellular prokaryotes. This finding might have serious implications for understanding the functioning of the microbial loop. Finally, because SSU rRNA databases have significantly been extended in recent years, we showed that the probe PLA886, which targets Planctomycete $16 \mathrm{~S}$ rRNA, labelled $87 \%$ of the picoeukaryotes by hybridising their $18 \mathrm{~S}$ rRNA. Consequently, the design of this probe should be refined for future studies, and the presence of similar changes in probe specificity should be checked regularly when using hybridisation-based techniques.
\end{abstract}

KEY WORDS: Picoeukaryotes $\cdot$ Bacteria $\cdot$ Hybridisation $\cdot$ Diversity $\cdot$ Symbiont

Resale or republication not permitted without written consent of the publisher

\section{INTRODUCTION}

Over the last $15 \mathrm{yr}$, molecular tools have been widely used to study picoplankton diversity. Among the available techniques, fluorescence in situ hybridisation (FISH) of rRNA oligonucleotide probes has proved to be the most powerful for quantitative studies in the natural environment (Pernthaler et al. 2002, Not et al. 2004). Marine picoplankton comprises a mixture of photosynthetic and heterotrophic prokaryotes and eukaryotes in variable proportions. In oceanic waters, photosynthetic picoeukaryotes $\left(10^{3}\right.$ cells $\left.\mathrm{ml}^{-1}\right)$ are known to be 1 to 3 orders of magnitude less abundant than cyanobacteria $\left(10^{4}\right.$ cells $\left.\mathrm{ml}^{-1}\right)$ and bacteria

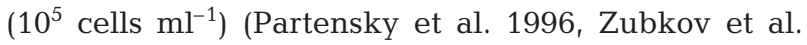
2000). In some of the few nutrient-rich coastal waters that have been investigated, photosynthetic picoeukaryotes $\left(10^{2}\right.$ to $10^{5}$ cells $\left.\mathrm{ml}^{-1}\right)$ can outnumber cyanobacteria by 1 order of magnitude (Biegala et al. 2003, Not et al. 2004) and be as numerous as bacteria, ranging from $10^{5}$ to $10^{6} \mathrm{cells} \mathrm{ml}^{-1}$ (Vaquer et al. 1996, Pernthaler et al. 2002, O'Kelly et al. 2003). Because 
picoeukaryote organelles (i.e. plastid and mitochondrion) are of eubacterial origin (i.e. cyanobacteria and alpha-proteobacteria, respectively) (Bhattacharya et al. 2003, Dyall et al. 2004), high concentrations of photosynthetic picoeukaryotes may introduce bias in the quantification of specific groups of bacteria when using 16S rRNA-targeted probes in FISH techniques. In addition, a limited number of studies have mentioned that picoeukaryote cultures can shield bacteria as intracellular symbionts; however, no quantitative estimates of such relationships are available from the natural environment (Guillou et al. 1999).

The aim of the present study was 2-fold: (1) to check whether commonly used general and specific eubacterial probes of the dominant marine groups also matched picoeukaryotic 16S rRNA or intracellular prokaryotes and (2) to assess the consequences, if any, of such unexpected hybridisations.

\section{MATERIALS AND METHODS}

Double hybridisation experiments, both on cultures and in natural samples, were carried aout in accordance with Biegala et al. (2002), using the general eukaryote probe EUK1209 (Giovanonni et al. 1988) labelled with fluorescein (FITC) in combination with different eubacterial probes labelled with Cyanine 3 (CY3) - EUB338 (Eubacteria, Amann et al. 1990), CYA664 (cyanobacteria, Schönuber et al. 1999), ALF968 (alpha-proteobacteria, Weisse 1993), GAM42a (gamma-proteobacteria, Manz et al. 1992), CF319a (Cytophaga-Flavo-Bacteria, Manz et al. 1996), PLA886 (Planctomycete, Neef et al. 1998) (Fig. 1). Cells were subsequently counterstained with 4',6-diamidino-2-phenylindole (DAPI) as previously described (Biegala et al. 2002). Two photosynthetic picoeukaryote strains, Micromonas pusilla (RCC114 or CCMP490, class Prasinophyceae) and Pelagomonas calceolata (RCC100 or CCMP1214, class Pelagophyceae), were grown under the same conditions as described in Biegala et al. (2003) and were sampled in exponential growth phase. Both strains where chosen because they were important members of the photosynthetic picoeukaryote community when the natural environment samples were taken (July 2002, coastal waters off Roscoff, Brittany, France, Fig. 1). In order to verify the presence of intracellular-labelled organelles or bacteria, images were acquired with a Zeiss 510Meta confocal microscope (Carl Zeiss) as recommended by Biegala et al. (2002) under identical conditions, with a $63 \times$ oil immer-
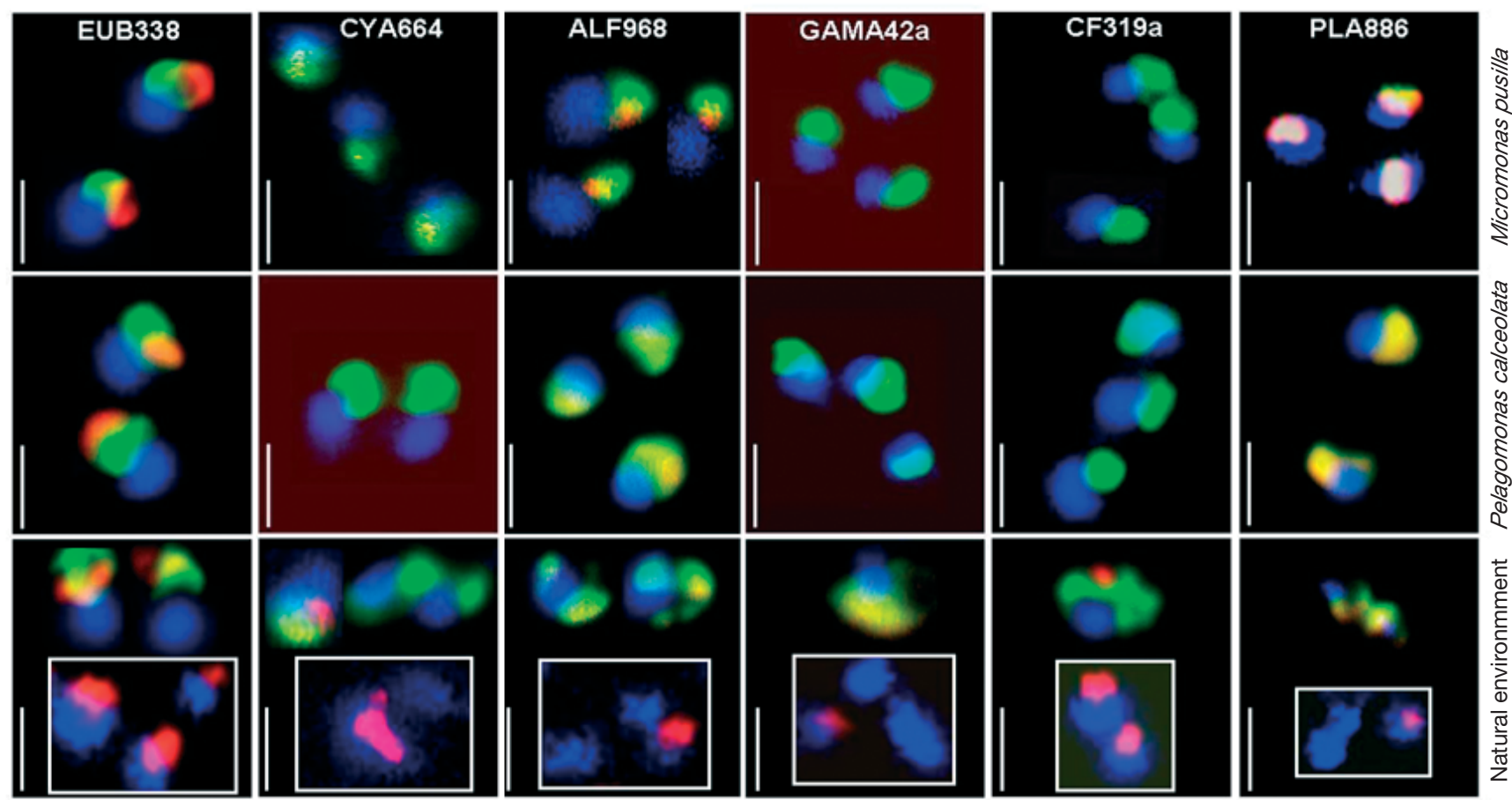

Fig. 1. Confocal micrographs of picoeukaryotes, both from cultures (Micromonas pusilla and Pelagomonas calceolata) and the natural environment (coastal waters off Brittany, France). Picoeukaryotes were double hybridised with the TSA-FISH (tyramide signal amplification-fluorescence in situ hybridisation) technique using the general eukaryote probe EUK1209 labelled with fluorescein (green) and using the general (EUB338) or group-specific (CYA664, ALF968, GAM42a, CF319a, PLA886) eubacterial probes labelled with Cyanine 3 (red). Free bacteria (framed sub-pictures) were abundant only in the natural environment and were successfully hybridised with either eubacterial general or group-specific probes. Prokaryotic and eukaryotic DNA was stained with 4', 6-diamidino-2-phenylindole (blue). Scale bars $=2 \mu \mathrm{m}$ 
sion objective (Zeiss NeoFluo N.A. 1.4) with appropriate excitation (ex.) and emission (em.) conditions for DAPI (80 mW Enterprise UV laser, ex. $364 \mathrm{~nm}$, em. filter 385 to $470 \mathrm{~nm}$ band pass), FITC ( $5 \mathrm{~mW}$ argon laser, ex. $488 \mathrm{~nm}$, em. filter 505 to $530 \mathrm{~nm}$ band pass) and CY3 (1.5 mW helium-neon laser, ex. $546 \mathrm{~nm}$, em. filter $600 \mathrm{~nm}$ long pass). Final images were reconstructions of Z-series of 15 to 18 images, each $0.7 \mu \mathrm{m}$ in depth, with a $50 \%$ overlap of each slice (Fig. 1). Counts were done with a standard epifluorescence microscope (Nikon Eclipse E800) equipped with a mercury lamp, a 100× oil immersion objective and adapted ex. and em. filters for FITC (ex. 465 to $495 \mathrm{~nm}$, em. 515 to $555 \mathrm{~nm}$ ) and CY3 (ex. $540 / 25 \mathrm{~nm}$, em. 605/55 nm). For each double hybridisation, counts were done over 30 fields to reach minima of 200 picoeukaryotes and of 6000 eubacteria (Table 1).

\section{RESULTS AND DISCUSSION}

In the present study, we showed that most of the commonly used eubacterial probes hybridised picoeukaryotes in cultures and in the natural environment. Previous work had indicated that the general eubacterial probe EUB338 hybridised plastids of some nano- and microphytoplankton, such as Prymnesiophyceae and diatoms (Biegala et al. 2002). The results presented in this study confirmed that EUB338 also hybridised plastids of the picoplankton Prasinophyceae and Pelagophyceae in cultures and $84 \%$ of the picoeukaryotes at the time of sampling (Fig. 1, Table 1), as this community is dominated by both classes of photosynthetic cells (Bieglala et al. 2003, Not et al. 2004). Among the eubacterial group-specific probes, CYA664 and ALF968 were expected to match either plastids or mitochodria, as these organelles are of eubacterial origin (Bhattacharya et al. 2003, Dyall et al. 2004). While ALF968 hybridised all picoeukaryotes in cultures and $16 \%$ from the natural environment, CYA664 surprisingly only hybridised Micromonas pusilla lightly in culture and $3 \%$ of the picoeukaryotes in the natural environment (Fig. 1, Table 1). Compared to the EUB338 probe, the amount of cells labelled by CYA664 was limited, which is probably due to mismatches with some 16S rRNA plastid sequences. These 3 probes hybridised picoeukaryotes often as a single dot, which indicates the presence of a unique plastid and/or mitochondrion, as has frequently been described for these tiny cells (Eikrem \& Thronsen 1990, Chretiennot-Dinet et al. 1995).

Gamma-proteobacteria and Cytophaga-Flavo-Bacteria $(\mathrm{CFB})$ are known to be 2 other dominant groups of eubacteria in the marine environment (Glöckner et al. 1999, Eilers et al. 2000). A BLAST search of GenBank confirmed that both GAM42a and CF319a probes, which respectively target the 2 above-mentioned groups, only matched eubacterial 16S rRNA and were not expected to hybridise any picoeukaryotes. Surprisingly, the probes hybridised 10 and $34 \%$, respectively, of picoeukaryotes from the natural environment (Fig. 1, Table 1). This could indicate that at least $44 \%$ of the picoeukaryotes hosted intracellular bacterial symbionts in the studied environment. Previous investigations showed that both picoeukaryotes and CFB were able to establish symbiotic relationships with either prokaryotes or protozoans (Guillou et al. 1999, Horn et al. 2001). The presence of intracellular bacteria could also be due to antagonist relationships, such as the predation of picoeukaryotes on bacteria, or the attack of bacteria on small algae (Cole 1982, Guillou et al. 2001). However, the strong fluorescent signals observed for CF319a and EUK1209 probes reflect the presence of healthy cells at the time of sampling and make this hypothesis less likely.

In future studies, the occurrence of such relationships should be checked in the natural environment, to

Table 1. Comparison of picoeukaryote counts over different groups of prokaryotes in the summer coastal water sample (Brittany, France), using the TSA-FISH (tyramide signal amplification-fluorescence in situ hybridisation) technique. N: number of fields counted; FITC: total number of fluorescein-labelled cells with eukaryote probe; CY3: total number of cyanine 3-labelled cells with prokaryote probes; FITC + CY3: total number of cells labelled simultaneously with eukaryote and prokaryote probes; \% FITC/CY3: percentage of eukaryote over each group of prokaryote; \% FITC + CY3/FITC: percentage of eukaryote hybridised by the different prokaryote probes; \% FITC + CY3/CY3: percentage of error in prokaryote counts due to intracellular eukaryote labelling

\begin{tabular}{|c|c|c|c|c|c|c|c|}
\hline $\begin{array}{l}\text { Probes used for double } \\
\text { hybridization }\end{array}$ & $\mathrm{N}$ & FITC & CY3 & FITC + CY3 & $\begin{array}{c}\% \text { FITC/CY3 } \\
(\text { mean } \pm \text { SE) }\end{array}$ & $\begin{array}{c}\% \text { FITC + CY3/ } \\
\text { FITC } \\
(\text { mean } \pm \text { SE })\end{array}$ & $\begin{array}{c}\% \text { FITC }+ \text { CY3/ } \\
\text { CY3 } \\
(\text { mean } \pm \text { SE) }\end{array}$ \\
\hline EUK1209 + EUB338 & 36 & 229 & 6001 & 192 & $4 \pm 2$ & $84 \pm 27$ & $4 \pm 2$ \\
\hline EUK1209 + CYA664 & 30 & 279 & 59 & 7 & $654 \pm 481$ & $3 \pm 9$ & $17 \pm 38$ \\
\hline EUK1209 + ALF968 & 30 & 246 & 2318 & 40 & $11 \pm 5$ & $16 \pm 14$ & $2 \pm 2$ \\
\hline EUK1209 + GAM42a & 31 & 222 & 1647 & 16 & $17 \pm 13$ & $10 \pm 17$ & $3 \pm 5$ \\
\hline EUK1209 + CF319a & 30 & 204 & 3689 & 60 & $7 \pm 5$ & $34 \pm 21$ & $2 \pm 2$ \\
\hline EUK1209 + PLA886 & 30 & 241 & 217 & 213 & $122 \pm 44$ & $87 \pm 19$ & $99 \pm 5$ \\
\hline
\end{tabular}


improve understanding of the ecology of both types of organisms. In this coastal sample, the community of picoeukaryotes was 1 to 2 orders of magnitude less abundant than the general eubacterial community, largely represented by $\mathrm{CFB}$, alpha-proteobacteria and gamma-proteobacteria (Table 1). Thus, errors due to picoeukaryote co-hybridisation were not significant and ranged from 2 to $4 \%$ (Table 1). However, for cyanobacteria, the least dominant group of picoplankton, a $17 \%$ overestimation of cell counts occurred (Table 1).

Finally, an increasing number of publications point to the wide distribution of planctomycetes (DeLong et al. 1993, Glöckner et al. 1999), as well as their important environmental activity (Strous et al. 1999, Glöckner et al. 2003). However, use of the PLA886 probe for investigation of the distribution of this group is questionable, as recent acquisition of sequences in GenBank revealed that PLA886 hybridises a large range of $18 \mathrm{~S}$ rRNA Prasinophyceae, including Micromonas pusilla. This study confirmed that $100 \%$ of both cultures and up to $87 \%$ of the picoeukaryotes from the natural environment were simultaneously hybridised by EUK1209 and PLA886 probes. Considering the relative number of planctomycetes compared to picoeukaryotes in the investigated samples, $99 \%$ of these prokaryote counts were erroneous.

\section{CONCLUSION}

In conclusion, most general and group-specific eubacterial probes hybridised picoeukaryotes in this study either because they detected eukaryotic organelles, or because of the presence of symbiotic or antagonist intracellular eubacteria. In the investigated environment, the proportion of picoeukaryotes over prokaryotes may vary significantly. We thus recommend the use of double hybridisation of prokaryotic probes together with general eukaryotic probes, particularly when investigating new environments. This would allow researchers not only to check the bias on cell counts of less well represented prokaryote groups, but also to investigate the presence of intracellular bacteria within picoeukaryotes. More information on these intimate relationships might improve our understanding of the functioning of the microbial loop. In addition, these double hybridisations may reveal with time that the specificity of some existing probes is not ideal and that the refinement of probe design may be required.

Acknowledgements. This work was supported by the European programs BASICS EVK3-CT-2002-00078 and PICODIV EVK3-CT-1999-00021. We thank Dr. D. Vaulot for useful discussion, as well as anonymous referees for helpful comments.

\section{LITERATURE CITED}

Amann RI, Krumholz L, Stahl DA (1990) Fluorescent-oligonucleotide probing of whole cells for determinative, phylogenetic, and environmental studies in microbiology. J Bacteriol 172:762-770

Bhattacharya D, Yoon HS, Hackett JD (2003) Photosynthetic eukaryotes unite: endosymbiosis connects the dots. BioEssays 26:50-60

Biegala IC, Kennaway G, Alverca E, Lennon JF, Vaulot D, Simon N (2002) Identification of bacteria associated with dinoflagellates (Dinophyceae) Alexandrium spp. using tyramide signal amplification-fluorescence in situ hybridization and confocal microscopy. J Phycol 38: 404-411

Biegala IC, Not F, Vaulot D, Simon N (2003) Quantitative assessment of picoeukaryotes in the natural environment using taxon specific oligonucleotide probes in association with tyramide signal amplification-fluorescence in situ hybridization and flow cytometry. Appl Environ Microbiol 69:5519-5529

Chretiennot-Dinet MJ, Courties C, Vaquer A, Neveux J, Claustre H, Lautier J, Machado MC (1995) A new marine picoeukaryote: Ostreoccocus tauri gen. et sp. nov. (Chlorophyta, Prasinophyceae). Phycologia 4:285-292

Cole J (1982) Interactions between bacteria and algae in aquatic ecosystems. Annu Rev Ecol Syst 13:291-314

DeLong EF, Franks DG, Alldregdge AL (1993) Phylogenetic diversity of aggregate-attached vs. free-living marine bacterial assemblages. Limnol Oceanogr 38:924-934

Dyall S, Brown MT, Johnson PJ (2004) Ancient invasions: from endosymbionts to organelles. Science 304:253-257

Eikrem W, Thronsen J (1990) The ultrastructure of Bathycoccus gen. nov. and $B$. prasinos sp. nov., a non-motile picoplanktonic alga (Chlorophyta, Prasinophyceae) from the Mediterranean and Atlantic. Phycologia 29:344-350

Eilers HJ, Pernthaler J, Glöckner FO, Amann R (2000) Culturability and in situ abundance of pelagic bacteria from the North Sea. Appl Environ Microbiol 66:3044-3051

Giovanonni SJ, DeLong EF, Olsen GJ, Pace NR (1988) Phylogentic group specific oligonucleotide probes for identification of single microbial cell. J Bacteriol 170:720-726

Glöckner FO, Fuchs BM, Amann R (1999) Bacterioplankton composition of lakes and oceans: a first comparison based on fluorescence in situ hybridization. Appl Environ Microbiol 65:3721-3726

Glöckner FO, Kube M, Bauer M, Teeling $\mathrm{H}$ and 10 others (2003) Complete genome sequence of the marine planctomycete Pirellula sp. strain. Proc Natl Acad Sci USA 100:8298-8303

Guillou L, Chrétiennot-Dinnet MJ, Boulben S, Moon-van der Staay SY, Vaulot D (1999) Symbiomonas scintillans gen. et sp. nov. and Picophagus flagellatus gen. et sp. nov. (Heterokonta): two new heterotrophic flagellates of planctonic size. Protist 150:383-398

Guillou L, Jacquet S, Chrétiennot-Dinnet MJ, Vaulot D (2001) Grazing impact of two small heterotrophic flagellates on Prochlorococcus and Synechococcus. Aquat Microb Ecol 26:201-207

Horn M, Harzenetter MD, Linner T, Schmid EN, Muller KD, Michel R, Wagner M (2001) Members of the CytophagaFlavobacterium-Bacteroides phylum as intracellular bacteria of acanthamoebae: proposal of Candidatus amoebophilus asiaticus. Environ Microbiol 3:440-449

Manz W, Amann R, Ludwig W, Wagner M, Schleifer KH (1992) Phylogenetic oligonucleotide probes for the major subclasses of proteobacteria: problems and solutions. Syst Appl Microbiol 15:593-600 
Manz W, Amann R, Ludwig W, Vacannyet M, Schleifer KH (1996) Application of a suite of 16S rRNA-specific oligonucleotide probes designed to investigate bacteria of the phylum Cytophaga-Flavobacter-Bacteroides in the natural environment. Microbiology 142:1097-1106

Neef A, Amann R, Schlesner H, Schleifer KH (1998) Monitoring a widespread bacterial group: in situ detection of planctomycetes with 16S rRNA-targeted probes. Microbiology 144:3257-3266

Not F, Latasa M, Marie D, Cariou T, Vaulot D, Simon N (2004) A single species, Micromonas pusilla (Prasinophyceae), dominates the eukaryotic picoplankton in the western English Channel. Appl Environ Microbiol 70:4064-4072

O'Kelly CJ, Seriaki ME, Their EC, Honson IC (2003) A transient bloom of Ostreococcus (Chlorophyta, Prasinophyceae) in West Neck Bay, Long Island, New York. J Phycol 39:850-854

Partensky F, Blanchot J, Lantoine F, Neveux J, Marie D (1996) Vertical structure of picoplankton at different trophic sites of tropical northeastern Atlantic Ocean. Deep-Sea Res I 43:1191-1213

Pernthaler A, Pernthaler J, Amann R (2002) Fluorescent in

Editorial responsibility: William Li,

Dartmouth, Nova Scotia, Canada situ hybridization and catalyzed reporter deposition for the identification of marine bacteria. Appl Environ Microbiol 68:3094-3101

Schönuber W, Zarda B, Eix S, Rippka R, Herdman M, Ludwig W, Amann R (1999) In situ identification of cyanobacteria with horse radish peroxidase-labeled oligonucleotides and tyramide signal amplification. Appl Environ Microbiol 65:1259-1267

Strous M, Fuerst JA, Kramer EHM, Logemann S and 5 others (1999) Missing lithotroph identified as new Planctomycete. Nature 400:446-449

Vaquer A, Trousselier M, Courties C, Bibent B (1996) Standing stock and dynamic of picophytoplankton in the Thau lagoon (Northwest Mediterranean coast). Limnol Oceanogr 41:1821-1828

Weisse T (1993) Dynamic of autotrophic picoplankton in marine and freshwater ecosystems. Adv Microb Ecol 13: $327-370$

Zubkov MV, Sleigh MA, Burkill PH (2000) Assaying picoplankton distribution by flow cytometry of underway samples collected along a meridional transect across the Atlantic Ocean. Aquat Microb Ecol 21:13-20

Submitted: April 4, 2005; Accepted: October 5, 2005 Proofs received from author(s): December 7, 2005 